\title{
INTERESTS OF BORDER COMMUNITIES IN WATER AND PASTURES: WILL THEY INFLUENCE NILE WATER POLICIES OF THE TWO SUDANS?
}

\author{
Samson S. Wassara ${ }^{1}$ \\ University of Juba
}

\begin{abstract}
:
This article examines relationships between cross-border pastoralists revolving around water and pastures. Water and pastures sustain livelihoods of people sharing common border between South Sudan and Sudan. Despite this commonality, competition between pastoralists of the Sudan and South Sudan has always degenerated into violent conflicts recorded since the period of Condominium rule. However, interests of the communities living along the Kiir/Bahr al Arab and the White Nile are localised. They are now more connected to disputed borders than to wider water rights. This article demonstrates that communal demands are politicized at the national and sub-national levels. Politics distract border communities from pursuing their realistic water access and grazing needs. It is concluded that pastoralist border communities are unable to influence land and water policies while South Sudan and the Sudan maintain hostile relations.
\end{abstract}

Keywords: Conflict, Grazing, Kiir/Bahr al Arab, Pastoralists, Transhumance, Water resources, White Nile.

\section{Resumen:}

Este artículo examina la relación entre los pastores trashumantes transfronterizos en torno a las los recursos acuíferos y de pastoreo. Tanto el agua como los pastos suponen el modo de vida de la población que comparte la frontera entre Sudán del Sur y Sudán. A pesar de tratarse de bienes comunes, la competencia entre los pastores nómadas de Sudán y de Sudán del Sur ha degenerado siempre en conflictos violentos registrados desde el periodo del Condominio. Sin embargo, los intereses de las comunidades que viven a lo largo del río Bahr al Arab (o río Kiir) y el Nilo Blanco están localizados. De hecho, en la actualidad están más relacionados con las fronteras disputadas que con el asunto más amplio de los derechos acuíferos. Este artículo demuestra que las demandas comunitarias están politizadas a nivel nacional y sub-nacional; y que la política distrae a las comunidades fronterizas de perseguir sus objetivos realistas de acceso al agua y a los pastos. Se concluye que las comunidades pastorales fronterizas son incapaces de influenciar las políticas de agua y tierra mientras Sudán del Sur y Sudán mantengan relaciones hostiles.

Palabras clave: Conflicto, pastos, río Bahr al Arab (río Kiir), pastores, trashumancia, recursos acuíferos, Nilo Blanco.

Copyright $\odot$ UNISCI, 2013.

Las opiniones expresadas en estos artículos son propias de sus autores, y no reflejan necesariamente la opinión de UNISCI. The views expressed in these articles are those of the authors, and do not necessarily reflect the views of UNISCI.

\footnotetext{
${ }^{1}$ Samson Samuel Wassara is Professor of Political Science in the University of Juba, and he is currently the Dean of the College of Social and Economic Studies. He obtained his PhD from the University of Paris XI in 1994. His research interests include statebuilding, security sector, peace studies and hydro-politics. Address: University of Juba, P.O. Box 82, Juba, South Sudan.

E-mail: wassara49@yahoo.co.uk; samsonwassara@hotmail.com.
}

http://dx.doi.org/10.5209/rev_UNIS.2013.n33.44810 


\section{Introduction}

The failure by partners of the Comprehensive Peace Agreement (CPA) to make unity attractive and the subsequent secession of Southern Sudan to become South Sudan in July 2011 is the root cause of the current plight of border communities of South Sudan and Sudan. The reactions to a de facto situation clearly demonstrates the two countries' unpreparedness to come to terms with realities of neighbourliness. So many factors come into play when bitterness replaces hopes of peace. It is becoming clear that conflicts between Khartoum and Juba are evolving into resource-centred instead of people-centred conflicts. The CPA ignored complexities of the common border and the people. Partners of the agreement fixed their dreams on further exploitation of resources until they were surprised when secession became a reality on the ground.

The issue of natural resources is at the centre of the yearning for independence in South Sudan from Sudan that was fulfilled in July 2011. Relations between the two countries are sour because of the lust for oil, one of the natural resources that generate immediate benefits for the governments in power. It is unfortunate that many of political discourses are devoted to oil wealth, which is a non-renewable resource. There do exist other renewable natural resources that shaped relations between the state and others, and between the people themselves. These resources are water and the land and pastures which helped maintaining permanent bonds between people and the state. Oil resources are just a new wealth, which condemns the present states to a bumpy path of coexistence. This paper focuses on the Nile water, a renewable natural resource that has determined relations between people and cultures for centuries. Unlike oil, which is likely to be exhausted in some years to come, water and pastures will continue to be a basis for coexistence in centuries to come.

Shaped inter-state and inter-communal relations, which will continue to exist after oil resources are exhausted. The role of water in the Nile River system's development dominated the economies of the Sudan and Egypt and this same water will continue to determine relations between South Sudan and Sudan in a similar fashion. Opportunities to increase water supplies for both Sudan and Egypt lie in the White Nile basin of South Sudan. In the other bracket of the equation, the Nile River and its tributaries have always been the lifeline for livelihood of communities that shared its water and the dry season pastures. ${ }^{2}$ In every society, there must be competition for survival. The communities that shared water and grazing lands during dry season found formulas of coexistence that may have fallen victim to unrealistic politics of instrumentalisation by governments of both South Sudan and the Sudan.

This paper does not deal with all border communities. Communities whose situation and relationships we will examine are located in the White Nile, the Bahr al Ghazal and the Kiir/Bahr al Arab river basins. A map ${ }^{3}$ marks their areas by the numbers in the following circles:

\footnotetext{
${ }^{2}$ Abdalla, Ali Jammaa: "People to People Diplomacy in a Pastoral System: A case from Sudan and South Sudan", Pastoralism: Research, Policy and Practice, vol. 3, n 12 (April 2013), pp. 2-4, at: http://www.pastoralismjournal.com/content/3/1/12.

${ }^{3}$ Map: Communal and Political Flashpoints along Sudan South Sudan Border. Map Adopted from Saeed, Abdel Basit (2010): Challenges Facing Sudan after Referendum Day, Bergen, CMI, p.10.
} 


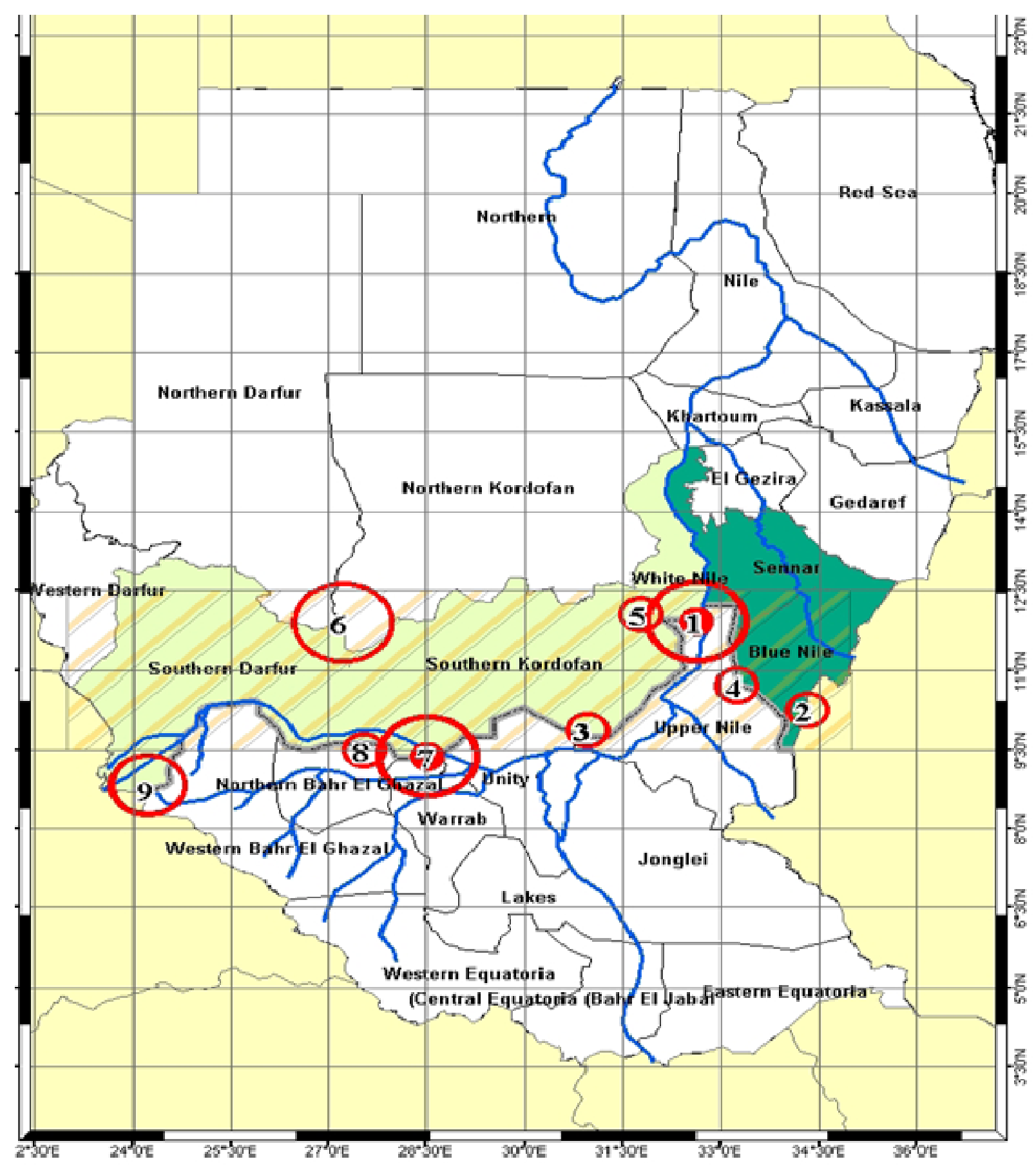

1. Number 8 are the Dinka Malual of Northern Bahr al Ghazal and the Baggara Rezeigat of South Darfur;

2. Number 7 are the Dinka Malual of Northern Bahr al Ghazal, the Dinka Ngok of Abyei, and the Baggara Misseriya Humr of South Kordofan;

3. Number 3 are the Dinka of Pariang, the Nuer of Unity State and the Baggara Misseriya Zuruk,

4. Number 1 are the Dinka Abliang, the Shilluk of northern Upper Nile and the Kawahla of South Kordofan, the Seleim, and the Ahamda of the White Nile state of the Sudan. 
These are the areas where the Sudan Armed Forces (SAF) and the Sudan People's Liberation Army (SPLA) used tactics of proxy wars before the CPA was signed. Realities on the ground have shown that while political elites continue to entertain their war-time grudges, the ordinary citizens persist in reviving peaceful coexistence at the local level. Despite independence of South Sudan and the wrangling between rulers in Juba and Khartoum, the border Dinka and Baggara communities continue to renew local contacts over human and livestock movements, border markets, sharing of water points and sharing of grazing areas. Conferences of Northern Bahr al Ghazal Dinka communities and South Darfur/South Kordofan Baggara communities in late 2011 are a case in point. ${ }^{4}$ The issues outlined above need an expanded exploration of the importance of the Nile River system to the two states and to their communities at the local level.

\section{Past Relations of Dinka and Baggara in the Kiir/ Bahr al Arab River Basin}

Mobility and transhumance are engineered by people searching for livelihoods and the survival of their domestic animals. The rain season and dry season are the determining factors in the timing of mobility in the border areas of South Sudan and the Sudan. ${ }^{5}$ Environmental degradation in the 1980s, the rise in livestock population, the establishment of large agricultural schemes blocking pastoral migratory routes and the civil war that ended in 2005 all contributed to a complex set of relationships not only between the border communities, but also between South Sudan and the Sudan.

Historically, the Nile River and its tributaries were a special economic resource for border communities in the Sudan. But the use of water was closely related to the climate and the modes of survival at the grassroots level. Researchers such as El Wakeel and Abu Sabah identify three groups of factors constraining the search for water and pastures: natural, sociocultural and political factors. ${ }^{6}$ For this reason, the Nile and its tributaries are factors of livelihood, but also the focus of inter-communal relationships. The importance of the Bahr al Arab River to transhumant communities is described by a nomad researcher inter alia:

The river's resources are utilised by the Malwal Dinka of North Bahr-al-Ghazal and pastoral Rizaigat of South Darfur, as well as by the Ngok Dinka and the Misseriya of South Kordofan. All see access to the Bahr-al-Arab as essential to their livelihoods. The relations between these groups have been marked by violent conflict for generations (sic). ${ }^{7}$

The Baggara pastoralists of Darfur and Kordofan states used to drive their herds of livestock towards rich grazing lands and water points of Kiir/Bahr al Arab and the White Nile River during the dry season. In so doing they interact and socialize with each other on the other side of the river banks separating them. These relations began to sour only when border

\footnotetext{
${ }^{4}$ Ibid., pp. 4-6.

${ }^{5}$ El Wakeel, Ahmed S. and Abu Sabah, Mohamed A., "Relevance of Mobility to Rangeland Utilization: The Baggara Transhumant of Southern Kordofan", Nomadic Peoples, n³2, (1993), pp. 33-35.

${ }^{6}$ Ibid., p. 34.

${ }^{7}$ Saeed, Abdelbasit, (2010): Challenges Facing Sudan after Referendum Day 2011: Persistent and Emerging Conflict in the North-South Borderline States, Bergen, CMI, p. 21.
} 
communities became politicized and eventually militarized since 1970s. Sharing water resources and grazing land by virtue of past agreements became adversely affected by recurrent civil wars that used to engulf border areas.

During the colonial period, the District Commissioner (DC) of the Northern District in Bahr el Ghazal province was responsible for the maintenance of the security and law enforcement in the Kiir basin. Dinka chiefs were made to be responsible for the cases that took place at the southern bank of the Kiir/Bahr al Arab. ${ }^{8}$ The cases of marriages, cattle theft, trade, abduction, rape and fighting over grazing and fishing pools in the southern bank of the river were addressed by Chief Anyoun Aturjong of Gok Machar with the help from Nazir Ibrahim Musa Madibo of Riziegat especially on those instances that Arabs might have committed a crime and crossed the river to Rezeigat Dar in Abu Matarik or Daein towns. Important cases such as inter-communal confrontations between groups at the river-side were suspended, awaiting the arrival of the DC of Northern Distinct of Bahr el Ghazal to the site. The role of the DC was not restricted to inter- tribal conflicts only. There were many cases involving intra-Dinka violence that the DC used to address. ${ }^{9}$ It is important to mention that some of the cases were directly investigated and settled by the DC of Northern Distinct of Bahr al Ghazal. ${ }^{10}$ However, certain cases that involved cattle thefts in neighbouring communities were settled by concerned chiefs. This was necessary for the maintenance of the peace and security in the Kiir/Bahr al Arab river basin. It was the Anyanya war against the Sudan Armed Forces (SAF) that changed inter-ethnic relations. The government took side with the Baggara tribes supplying them with weapons.

During Nimeiri's regime and after the Addis Ababa Agreement in 1972, the security situation deteriorated, resulting in the proliferation of small arms in the area. The proliferation of small arms was a deliberate policy of the government to displace the indigenous population for the purpose of minerals exploration. The four-year period following implementation of the agreement was a tough one. It is reported that approximately 600 people from the Dinka Malual community lost their lives, compared to only 60 people from Rezeigat tribe at Safaha. The Malual sustained heavy losses due to the imbalance in arms supply to the parties involved in the communal conflict. For the first time, the Rezeigat used A4Ks and G3 rifles supplied by the SAF which gave them an advantage in the battle field. The Anyanya forces at Mathiang Garrison were compelled to supply Dinka Malual after the horrible battle of 1974 at Safah. The start of the second civil war in the South Sudan resulted in increased intervention by parties to the conflict in communal conflicts in South Darfur and West Kordofan. The warring parties supported the communities of both sides of the war divide. The politicization and militarization of border communities resulted in the escalation of conflicts and the polarization of the groups along racial lines. ${ }^{11}$ For example, the emerging alliance between the Dinka, Zaghawa and Maaliya against the Baggara groups became an established pattern of conflict in the Sudan.

The government recruited the Baggara, Anyanya II, and the Nuer militias who were active in border areas as early as 1983. The Muraheleen tribal militias were formed in the mid-1980s. The various groups were merged to form the Popular Defence Force (PDF) after 1989. Since then the term "Muraheleen" was applied to all militias groups of the Rezeigat and Messeiriya Baggara tribes and to denote tribal militias who raided villages in the Sothern

\footnotetext{
${ }^{8}$ International Crisis Group (ICG) (2010): Sudan: Defining the North-South Border, Africa Briefing No 75, p.9.

${ }^{9}$ Governor of Equator, Letter No. 86-A-1-1/SCR, dated 20/6/1925.

${ }^{10}$ J.M. Stubbes, DC/ND, Letter No N.D/66.B.13, dated 17/4/1930.

${ }^{11}$ Craze, Joshua (2013): Dividing Lines: Grazing and Conflict along Sudan-South Sudan Border, Geneva, Small Arms Survey, Graduate School of International Development Studies, pp.45-50.
} 
Sudan. The Muraheelen were armed by the SAF to attack their Dinka neighbours since 1985 . The Dinka were regarded as the civilian base of the SPLA, and the Baggara (and soldiers) were and are rewarded with total impunity and war booty: cattle, grain and human beings (women and children). ${ }^{12}$ Often the Muraheelen conducted joint operations with the army. The raids expanded as the civil war progressed with very devastating effects on Dinka communities. The government turned to arming the Baggara as militias in the past because conscription was unpopular in Sudan. The traditional role of the Muraheleen was to accompany the herds of cattle ahead of the rest of the tribe in the seasonal movement of the herds; they travelled on horseback, and were traditionally armed to protect themselves and their herds against wild animals and cattle raiders. The equivalents of the Muraheleen among the Rezeigat of South Darfur are called "Fursan", the Arabic word for horsemen.

One important function of the Muraheleen since 1989 was to accompany the military supply train to Wau. They put their horses on the train, which were taken out on reaching Bahr el Ghazal and used against Dinka villages. The Dinka, who do not have horses, also lacked modern weapons and protection because Northern Bahr el Ghazal was not considered of strategic military importance to the SPLA. One of the consequences of the deliberate policy of transferring formal into informal warfare contributed to the spread of violence and insecurity across the countryside. The divide-and-rule military tactics of the warring parties in the major conflict areas produced sharp differences between the Misseriya and the Dinka who used to share grazing land, watering points and the like. This unfolding event destroyed the vital traditional systems of maintaining peace between communities in the border areas.

The two groups seem to have realized the destructive consequences of the external interventions in their "local politics". For the Rezeigat, the new reality was that their future survival depended in re-establishing good relations with the Dinka. The number of conferences and peace treaties during the past few years appears to be a manifestation of this new realism. Both groups realized that in spite of the often bad relations, intermarriages take place, (mostly with Rezeigat marrying Dinka girls). The complexion of many Rezeigat and Misseriya Zuruq (Black Misseriya) probably reveals this fact of intermarriages. Prior to independence, even during the period of the "Closed District Ordinance", both groups were brought together annually to attend conferences that reviewed the relations between them. Chiefs from other parts of South and North Sudan were brought to attend these conferences. All disputes were settled in these meetings, including the payment of 'diya' (blood money), return of stolen cattle and abducted girls.

The Dinka/Baggara rivalry escalated from tribal animosity to a government strategy of counterinsurgency operations in which some of the Baggara groups became government proxies in military expeditions against the Dinka of Northern Bahr al Ghazal and the Ngok Dinka. The latter were perceived as the backbone of the SPLA/M. This role for the Misseriya was forged under the Military rule of Nimeiri and applied by the Democratic Government in 1986-89. The Babanusa-Aweil-Wau railway corridor is one of the most important routes linking the South to the North. Since its completion the railway reduced the importance of the river route to Wau. This corridor had played a significant role in all South-North conflicts.

In the past, the government had strict control over the annual movement of the Misseriya to the dry season grazing areas, but with time this control became loose and the Misseriya had less fear of camping in Nuer and Dinka during this part of the year. The Misseriya regarded all land as belonging to the government and, therefore, they claimed the

\footnotetext{
${ }^{12}$ Jok, Jok Madut (2007): Sudan: Race, Religion, and Violence, Oxford, One World, pp.216-217.
} 
right to use it. Thus, disputes arose between the Misseriya, the Dinka and the Fellata nomads from West Africa who also used the area for grazing.

Mechanisms used to exist for settling conflicts between the Baggara and the Dinka, mostly by inter-tribal conferences backed by the power of the state. Agreements between the two sides produced truces from time to time. During the first civil war (1955-1972), the Baggara entered into grazing agreements with local commanders of the Anyanya southern guerrilla movement. They paid taxes in form of money or cattle in order to graze and water their livestock in Bahr el Ghazal during the dry season. These agreements were not renewed at the outset of the second civil war. However, the Baggara began to make annual armed incursions into Bahr el Ghazal and Upper Nile, taking advantage of the local unarmed populations. Since the beginning of the second civil war in 1983, the national government did not intervene to settle disputes between the Baggara and the Dinka.

Annual peace conferences were an effective mechanism for addressing issues emerging from continuous interaction over grazing and water for a whole year. These conferences were useful in mitigating tension among border communities. The security and organization of migratory grazing routes were among items of the agenda of peace meetings. During the colonial era, Safaha at the southern bank of the Kiir/ Bahr al Arab was identified as the seat of peace meetings. The reconciliation conference convened in Babanusa in 1976 recommended appointment of the joint security committee at Safaha, with equal representation while the leadership of the committee alternated between the Dinka and the Baggara. The conference also recommended the formation of the grazing committee to be responsible for the pastures and water. It was also recommended that the river be a temporary borderline between the two provinces of Bahr el Ghazal and Darfur until the issue of the boundary would be resolved. ${ }^{13}$ Furthermore, the Rezeigat tribe committed themselves to the payment of 450,000 Sudanese pounds as $\mathrm{Dia}^{14}$ for the victims, whereas one-third of the total were paid to Aweil District authorities, but could not reach the families of the victims.

The May Revolution under the leadership of Jaafar Nimeiri assumed power in Sudan with his socialist agenda, targeting the native administrational institutions. President Nimeiri decreed the liquidation of native administration in 1975 and replaced the system with basic units of the Sudan Socialist Union (SSU). ${ }^{15}$ This unfortunate step from Khartoum affected the peaceful coexistence between the two communities because the institution, which was known for its dedication to maintaining communal peace, was not longer there. In 1976, the regime decided to shift the location of meetings from Safaha to Babanusa. The change in the location of the meetings was imposed by an incident, which took place at Safaha during the conference in 1974 when a certain Rezeigi notable declared in preparatory meetings that the children will play tomorrow, a threat which meant more fighting. Indeed, the fighting occurred on that day. Therefore, the authorities decided to shift the venue of the meetings to Babanusa and it continued to host the conferences for five years until the eruption of the civil war in 1983.

The area under study in this section provides an example of the relationship between two groups that have the same economic background, but who differ with respect to religion and "race", and where the impact of the current civil war has been immense on both human and animal population. The Kiir/Bahr al Arab region is the transitional zone that links the

\footnotetext{
${ }^{13}$ Minutes and resolutions of the Reconciliatory Conference, Babanusa, 1976.

${ }^{14}$ Dia is the blood compensation in form of money or cows.

15 Wol, Dhieu M. Diing (2010): Pastoralists, Boundary and Dispute: The administration and conflict management in 14- Miles south of Kiir/ Bahr el Arab, (unpublished paper presented at a meeting of the African Union High Implementation Panel), pp. 24-29.
} 
South and North of Sudan, which for over the last three centuries has been the meeting point of two different cultures, the African culture represented by the Dinka and the Arab Culture represented by the Baggara. However, it is also noted that the racial divide between the two groups is blurred because of the long history of contact and inter-marriages between them. It is also a zone where the two cultures melt producing groups, such as the Misseriya Humur, which is a blend of both cultures through intermarriage and assimilation. The opposite is also true for the Dinka many of whom claim ancestry to the Rezeigat, although the numbers are reported to be small. ${ }^{16}$ This zone extends from the western borders of Sudan with Chad and Central African Republic across the Southern Parts of Darfur and South Kordofan to the borders with Upper Nile where Kiir/Bahr al Arab joins the Bahr al Ghazal to enter the Bahr al Jebel. ${ }^{17}$ It is the dry season meeting point by the two groups of predominantly cattle pastoralists. The use of the resources of the Kiir/Bahr al Arab Region has resulted in the development of strategic interests by the two groups upon which economic, social and political relations have emerged, and which are being manipulated today by new actors. The Bahr al Arab (Kiir) is not only a meeting point for the Dinka of northern Bahr el Ghazal and the Baggara; here they come to fish and market their goods including livestock. ${ }^{18}$

The two groups are mainly pastoralists rearing cattle of goats and sheep, with some camels among the Rezeigat practicing a transhumance form of mobility and nomadism. The climatic conditions dictate the pattern and distance of human and animal movement and their concentration during the different periods of the year. While the Baggara are nomadic, the Dinka practice some form of transhumance. The Baggara nomads move from North Darfur to Kiir/ Bahr al Arab River, while the Dinka move their cattle to the area during the peak of the dry season, and they also use part of the area for agriculture. The Dinka generally stay in the area for about three months between December and March/April and they move back to the areas of permanent settlements where they carry out crop production. The Baggara stay a longer time in the area than the Dinka, often lasting between six and eight months depending on climatic conditions in the North. The length of movement of nomads to the North is related to the amount of rains, availability and avoidance of muddy areas. ${ }^{19}$

The Dinka who own comparatively large numbers of cattle practice a certain form of transhumance, which has certain points of similarity and certain points of contrast with that found in the semi-arid zone occupied by the Baggara. The Dinka move from the Kiir/Bahr al Arab to their settlements where rainfall is heavier. The Nomads, on the other hand, move into areas of lighter rainfall during the wetter months and from these areas to dry season grazing land during the year. ${ }^{20}$ Superficially their annual cycle of movements appears identical with that of the Dinka. In fact, their movement is conditioned by the amount of pasture and water available on the routes. These physical conditions determine the concentration and distribution of the population during the different seasons. However, the cycle of movements is much the same, though the actual timing of the movements is different, since in the areas of the nomads the rains do not start until June/July, long after the Dinka have moved back to

\footnotetext{
${ }^{16}$ Nyang'oro J.E. (2001): The Effectiveness of Civil Society Initiatives to Controlling Violent Conflicts and Building Peace: A Study of Three Approaches in the Greater Horn of Africa. Case Study Four: Local Level Intergroup peace Building in Southern Sudan: An Assessment of Effective Practices; Management System International.

${ }^{17}$ Saeed, Abdelbasit, op. cit., pp. 7-13.

${ }^{18}$ Nyaba, Peter Adwok (2001): Trading Bridge in Northern Bahr el Ghazal: Transforming the Dinka-Baggara Conflict through Increased Economic Activities in the Transition Zone, Paper presented at the Conference "Money Makes the War Go Round: Transforming the Economy of War in Sudan", Brussels, 12-13 June. Can be accessed at http://www.cmi.no/sudan/resources.cfm?page $=48$.

19 El Wakeel, Ahmed S., op.cit., p.35.

${ }^{20}$ Abdalla, Ali Jammaa, op. cit., p. 3.
} 
their cultivations in normal times. Moreover, the actual movement of the cattle camps is relatively similar; at the initial stage of the movement, the camps are relatively small, composed of the smallest lineage groups (farig) first, and then of larger groups as the peak of the dry season approaches. The maximum period of concentration is at the peak of the dry season just before the onset of the rains.

Traditionally the location of the cattle camps of the different groups were made by agreement in an annual conference organized by local government authorities prior to the movements of the cattle into the zone. The duration of stay of each group, in particular that of the Baggara groups was determined during these conferences, although climatic conditions, such as the start of the rains and the availability of water and grazing in the North where the Baggara would move, were also important factors.

Disputes, often resulting into violent conflict, appeared to have been a norm in the relations between the two cultures; but also traditional mechanisms developed over the centuries that not only resolved such disputes/conflicts but also to prevent their occurrence. The expansion in numbers of both human and animal populations over the centuries, coupled with deterioration in the natural conditions in the northern parts of Sudan, resulted in an increased pressure over the resources of the Kiir/Bahr al Arab River; moreover, the Baggara groups tended to stay longer in the area than in the past. This led to increased disputes and conflicts over the years, and the weakening of the traditional administrative structures increased the cycle of violence in the zone.

In 2004, the Dinka, Messeriya and Rezeigat (DMR) communities went to Addis Ababa with help from the Sudan Government and SPLM/A to negotiate inter-communal peace and find ways of supporting peace negotiation in Naivasha. The meeting issued a communiqué calling for the acceleration of the peace process. The meeting also called for the conference of border communities at home to address issues of enhancing good neighbourhood ${ }^{21}$. However, the meeting did not take place until 2008 in Aweil. The delay was a result of a dispute over the venue of the conference and the introduction of the highly politicized Abyei agenda at the conference. It was from that time onwards that the town of Aweil continued to host annual peace conferences, between Dinka Malual and Rezeigat on one hand, and Dinka Malual and Misseriya on the other hand. The last meeting between Dinka Malual and Rezeigat communities identified 37 conflict issues, including pastures and water. ${ }^{22}$ It was convened at Gok Machar in 2012. In brief, what is important in these conferences is the readiness of Dinka Malual to allow Rezeigat cattle to go as far as they could do, as long as they do not carry guns with them.

As the civil war broke out again in 1983 it progressed at a terrific speed resulting in politicization and militarization of the Baggara groups in South Kordofan and South Darfur. These groups, mainly the Misseriya and the Rezeigat communities were instrumentalized as agents in the proxy war. ${ }^{23}$ They accompanied trains supplying the Sudanese army in Bahr al Ghazal. The rival border communities engaged in cattle rustling and child/women abduction as a source of wealth. The embittered border communities in Southern Sudan sought assistance from the SPLA to defend their families and animal wealth. ${ }^{24}$ This type of

\footnotetext{
${ }^{21}$ Dinka-Misseriya-Rezeigat (DMR), Communiqué of Addis Ababa, 18/2/2004.

${ }^{22}$ Gok Machar Meeting, Final Report, Resolution and Recommendations, 2012.

${ }^{23}$ Douglas H. Johnson (2011): The Root Causes of Sudan's Civil Wars, Revised Edition, Kampala, Fountain Publishers, pp.81-82.

${ }^{24}$ Concordis International and United States Institute of Peace (USIP), More than a Line: Sudan's North-South Border, (Report September 2010), pp.42-46.
} 
confrontations reached their limit as the war was taking long time to end. Border communities in this region felt they were being exploited and consequently sought honest reconciliation. They entered agreements on peace markets where they interacted, transacted and coexisted in peace despite war. Despite secession and independence of South Sudan, border communities tend to understand themselves and revive old alliances and communal compacts without governments as intermediaries. ${ }^{25}$ Instead, conflicts between their respective governments ignite crises that are transposed as conflicts to border communities.

\section{The Shilluk and Sudan Pastoralist Groups along the White Nile}

The nature of the relations described and analyzed below is to some extent different from the other conflicts in parts of South Sudan. Upper Nile is an important dry season grazing area for the nomadic groups from the Kosti and South Kordofan and although the disputes along the White Nile are partly related to the utilization of the natural environment by the nomads and the Shilluk groups, seasonal disputes involve the authorities in South Kordofan, White Nile and Upper Nile States because of the changes in administrative boundaries and movements of pastoralists of the Sudan taking place along the White Nile. Territories of South Sudan and the Sudan border each other along the White Nile. They are northern Upper Nile, eastern Nuba Mountains and the Blue Nile. ${ }^{26}$ The Shilluk and the Dinka live on the ridges of high ground close to the White Nile on its west bank. Few Shilluk live away from the river, notably on Khor Atar 20 kilometres inland from Kodok. Under the present distribution and system of land use the area has little use of wells, but increasing population and soil deterioration in the riverain area points to a future necessity for inland water supplies.

The economy of the Shilluk ${ }^{27}$ is still of the subsistence type, adapting to the nature of the physical environment. The economy depends on a balanced utilization of land, and they are more dependent on crop production than the Nuer and most of the Dinka groups. The seasonal movement of the population is limited compared to these other groups. Cultivation is carried in the toich, the highlands and in the hinterlands. The vegetation west of the Nile on the Shilluk side is characterized by thick growth, although part of the area is made up of open plains of grassland. Fishing is the second most important source of food and income for the Shilluk. Cattle has declined significantly among the Shilluk.

Mainly several Arab, the Alwad Surur and Kawahla groups, inhabit Kalogi Locality, which borders Fashoda in Upper Nile. The Arab groups, together with those of Kosti use this area for grazing during the dry season. However, the groups using Fashoda County for grazing include the nomads from Kosti in the White Nile State, mainly the Seleima and the Ahamda nomads. The Seleima are the largest and most compact group who claim Guhayna origin like most Baggara sections in the west. The Seleima mainly keep sheep and they exploit this area more than the Ahamda. Inland water supplies in the dry season are extremely scarce and a fair amount of grass is left untouched since the animal stock is driven to the river early in the season. After that only a strip of land which can be reasonably grazed by livestock

\footnotetext{
${ }^{25}$ Ibid., pp. 47-48.

${ }^{26}$ Craze, Joshua, op. cit., pp.133-144.

27 Evans-Pritchard, Edward E. (1948): The Divine Kingship of the Shilluk of the Nilotic Sudan (The Fraser Lecture), Cambridge, Cambridge University Press.
} 
watering at the river every second day is utilized, and by the end of the dry season it is grazed flat. $^{28}$

The Shilluk who own a few numbers of cattle practice a certain form of transhumance, which has certain points of similarity and certain points of contrast with that found in the semi-arid zone. The Shilluk cattle moving from the toich to the settlements is not conditioned by the rainfall but by the rise and fall in the levels of the river. They cannot move to a region where rainfall is lighter. The Nomads, on the other hand move into areas of lighter rainfall during the wetter months of the year. Superficially their annual cycle of movement appears identical with that of the Shilluk. In fact, their movement is conditioned by the amount of pasture and water available on the routes. These physical conditions determine the concentration and distribution of the population during the different seasons. However, the cycle of movements is much the same, though the actual timing of the movements is different, since in the areas of the nomads the rains do not break until June, long after the Shilluk cattle have moved back to their cultivations. Reeds, which grow on the numerous islands on the White Nile, are cut by the Shilluk and provide an important source of income. The reeds are sold in most towns of North Sudan for roofing and fencing. The practice of burning grass near the rivers and on the islands by the nomads during the dry season results in the loss of these reeds and is a source of conflict.

The boundary between the semi-arid region of the nomadic groups and the Flood Region of the Shilluk is set at Melut, east of the White Nile. On both sides of the Nile the inland dry season pasture and water supplies are insufficient for the Arab cattle owners of the northern part and there is constant pressure southwards to the river swamp pastures of the Shilluk. This is not a recent trend, but in the past public security required that grazing boundaries were fixed and that the number of "invading" livestock be determined by agreement. Thus, nomadic groups, in particular the Ahamda and Seleim Arabs, take their livestock from Kosti across Upper Nile border into Shilluk land as far South as Torakit. In considering the degree of pasture utilization in this area, there were administrative arrangements put into place, and no tribal rights disputed this point, although the nomads often contest this right. In the past the movement of the Seleim Arabs to Upper Nile during the dry season was regulated by agreement between them and the Shilluk King who gave authority to the chiefs to allocate specific grazing areas and routes to the nomads and in return collect taxes for the use of the land from these groups. ${ }^{29}$ This traditional practice was undermined by the present civil war.

Studies indicate that the nomadic groups such as the Seleim, Sabaha, Ahamda and the Rufa'a trespass the territories of the Abaliang Dinka around Renk and of the Shilluk to the South. These nomadic groups are increasingly involved in animal rustling (cattle and sheep). Thus, a conflict has been developing on the western part of Upper Nile between the Abliang Dinka and the Shilluk on the one hand and the nomads who come to graze on the banks of the River Nile during the dry season. ${ }^{30}$ The incident of Jebelein town in 1990 when many Shilluk were victims of attacks by the Arab groups marked a turning point in the Shilluk/Nomads relations.

This conflict can be described as a resource-based conflict between the nomads and the farmers and a border conflict between two localities, Fashoda in Upper Nile and Talodi in

\footnotetext{
${ }^{28}$ International Crisis Group, op. cit. pp. 5-7.

${ }^{29}$ Ibid., p.7.

${ }^{30}$ Saeed, Abdelbasit, op. cit., pp. 16-17.
} 
South Kordofan. The first type of conflict is traditional, which appears to have escalated during the past few years partly because of the civil war as a result of the breakdown in the traditional arrangements regulating the use of pastureland and access to water on the River Nile. The nomads from the Kosti area and from South Kordofan who use Shilluk land during the dry season have in recent years adopted a hostile attitude towards the Shilluk and no longer honour past agreements regulating their access to the dry season pastures. The 1989/90 violent conflict between the Shilluk and the nomad groups in Jebelein Area in which many Shilluk lost their lives, made the Arab groups have a feeling of superiority over the Shilluk who were regarded as supporters of the SPLA/M. The civil war was felt in this North-South border area during the 1980s and early 1990s when attacks by the SPLA resulted in a large number of displaced people who fled their agricultural lands to areas North of Jebelein and to Kosti and Rabak towns. Although the Shilluk were affected equally by these attacks, they were regarded as allies of the SPLA and they became targets of the Arab groups in the area.

\section{Discussion: Water, Pasture and Communities}

In many parts of border zones of South Sudan and Sudan, human and animal life depends on the delicate balance of ecosystem. During the last four decades this equilibrium was upset, particularly in the vast arid and semi-arid areas of the northern half of the country. In addition to the persistent drought, unsustainable methods of land use and overgrazing in marginal lands are destroying the eco-zone of many parts of Sudan, forcing many communities to abandon their areas and move to new ones in search of survival. Desertification and overexploitation of natural resources undermines the support systems that human life depends on, reduce carrying capacity, and increase the competition for nominally renewable yet scarce resources. In some areas, rapidly expanding human and livestock populations are outstripping the carrying capacity of the local resource base.

Those conflicts resulting from competition for water and grazing land were treated before South Sudan and Sudan were separate countries as isolated local disputes, which are not linked to national politics. Local governments in border areas dealt with issues of grazing, water, movement of livestock as petty disputes since the colonial period. It was not in their interests to sensitise pastoralists about their collaboration to articulate their demands for sharing water resources and grazing lands within the framework of national water policies.

Equally important, depletion of grazing lands and inequitable access to natural resources are also seen as a main cause contributing to previous, ongoing and potential future conflicts in the border areas. The management and resolution of conflicts raises a number of issues rotating around access to natural resources. This is widely seen as the cause of actual and potential future conflicts in many parts of South Sudan and Sudan, in particular, conflicts between pastoralists and settled agriculturalists, the local governments and/or other interest groups. Thus, it is also recognized that resolving and mitigating conflicts at the local level related to access to natural resources and services is an important aspect of development and service delivery.

The degradation and depletion of natural resources is a critical issue in several parts of the two Sudans, both in terms of environmental perspectives and in terms of impact on economic livelihood and poverty in which natural resources (mainly crop production and livestock) form the backbone of the economy. Organizing conflict management and resolution, access to and the quality of natural resources and social services, as well as 
reducing poverty can be the basis for ending conflicts through civil society building, which can enhance the ability of communities to work jointly for rational utilisation of scarce natural resources such as water and pastures.

In the post-CPA period the resurgence of ethnic intolerance in border areas suggest more potent and alarming threats to political stability in South Sudan and Sudan. Ethnic intolerance is resulting in extensive and protracted violations of people's livelihoods masterminded by the emerging governments. It is clear from negotiations between Juba and Khartoum that they are linking the use of pastures and water to territorial expansion in order to carve parts of the border water basins into their respective territories. Ethnic intolerance puts into jeopardy the peace compacts that communities in these regions had cultivated and nourished over centuries. Strategies of both South Sudan and Sudan sideline grassroots communities to manage pastures and water as in the past.

The independence of South Sudan has not only affected the legal regime and has established plans for exploitation of water and grazing lands in the border areas, but has also sent a wave of fear in the community of nomads that their livestock may perish. Thus the tendency to use force by border pastoralists is always lurking in the background. South Sudan and the Sudan are geographically located in the heart of Nile water disputes where cultural cleavages are manipulated to nurture political instability. Existing water-related policies focused on projects in the modern sector such as the Gezira scheme on the Blue Nile and pumping schemes along the White Nile at the expense of communities. It is in the interest of the two countries to engage in principled negotiations to place interests of border communities in the forefront of policies on the utilisation of water resources. The logical thing to do is to plan for collection of data with relevance to local consumption of water by communities and livestock. It is feasible to seek assistance of Nile water organisations and to solicit technical assistance from international organisations such as the UNDP and the World Bank. These organisations are already providing technical assistance to the Nile Basin Initiative (NBI) member states and institutions. ${ }^{31}$ It is expected that South Sudan and Sudan will adopt a clear position on community-based utilisation of water resources and grazing land.

While negotiating international and regional agreements on water resources, communities should be sensitised about benefits of inter-communal cooperation for the utilization of water and grazing areas. This is where people-to-people consultations among pastoralist groups should be encouraged to form associations of water and pasture users in the borderlands. Despite the uneasy peace that followed the CPA, the communal use of water and water related resources was constantly interrupted by violence in areas such as Abyei. The secession of South Sudan has just accentuated the already tense relations along the common border with the Sudan. This situation affects adversely border communities. Politicians in Khartoum and Juba pursue contradictory policies at the expense of grassroots people who have less to gain from the inter-state tensions. Local communities are conscious about their interests to enter into compacts at the border levels. This trend of mutual understanding is demonstrated by a number of inter-communal compacts among the various pastoralists in the border zone.

\footnotetext{
${ }^{31}$ Kagwanja, Peter: "Calming Waters: The East African Community and Conflict over the Nile Resources", Journal of Eastern African Studies, vol. 1, no. 3 (2007), pp. 323-333; Okoth, Godfrey P. "The Nile River Question and Riparian States: Contextualising Uganda's Foreign Policy”, African Sociological Review, vol. 11, no. 1 (2007), pp. 85-88.
} 


\section{Concluding Remarks}

The current disputes between South Sudan and Sudan are a short-term anomaly, which affects relations among grassroots border communities. They result from tempers resulting from secession that will take time to calm down. Sudan's post-CPA politics were marred with disputes that led many average citizens in southern Sudan to believe in secession as a better political solution. The main factor in the deterioration of relations between South Sudan and the Sudan is the continuation in power of the former foes who believe that stability of the region depends on the elimination of the other and the installation of a friendly government. The two states are responding to disputes without caring about the livelihood of their citizens who share critical resources for their survival. The border communities are to some extent responsible for the sustained intractability along the rivers providing water and grazing land to their livestock. So long as the communities pay allegiance to or take sides with the governments, it is certain that the status quo will continue for a while. It remains to be seen how people-to-people relations would develop irrespective of the antagonisms dominating the political landscape in South Sudan and the Sudan.

There are many challenges the two countries should strive to overcome in order to engage border communities as beneficiaries of substantial water and grazing land investments and services. The first issue is how to pursue diplomatic goals in order to preserve vital water interests in a region ridden by political conflicts. The two countries entangle themselves in disputes that hamper progress in communal utilisation of water resources. Their relations call for flexibility to avoid controversies that involve to a certain degree the communities of Kiir/ Bahr al Arab, Bahr al Ghazal and the White Nile river basins in the management of pastures and the utilisation of water resources. The exploitation of water resources and rich grazing land in border areas requires political stability. Volatile political situations in the border areas have contributed to general poverty among community users due to lack of coherent mobilisation of resources for development of water and pastures. It is incumbent upon South Sudan and the Sudan to ensure that friendly and stable governments exist to continue the exploitation of the renewable natural resources that bind communities of the two countries.

In summary, the border communities are hardly organised to face the challenges that affect their livelihoods. They lack the skills and values to determine their destinies in the complex situation. They accepted the status quo laid down during the colonial period where localised border conferences were organised for them by local government authorities to dialogue on predetermined issues. Pastoralists on both sides of the border have not engaged local authorities and national governments to formulate policies that should inject their local demands into national interests. Their satisfaction with local level compacts under the auspices of local governments undermines their effectiveness to influence national policies on water and grazing lands in border areas. It is a long way for border communities to strategise and push forward their demands into national policies as long as they contemplate solutions to their problems through policy-makers who have flimsy ideas about livelihoods in grassroots communities. 